\title{
Anxiety disorders and age-related changes in physiology - ERRATUM
}

\author{
Julian Mutz, Thole H. Hoppen, Chiara Fabbri and Cathryn M. Lewis
}

\section{Keywords}

Ageing; anxiety; body composition; cardiovascular function; physiology.

\section{Copyright and usage}

(c) The Author(s), 2022. Published by Cambridge University Press on behalf of the Royal College of Psychiatrists. This is an Open
Access article, distributed under the terms of the Creative Commons Attribution licence (https://creativecommons.org/ licenses/by/4.0/), which permits unrestricted re-use, distribution, and reproduction in any medium, provided the original work is properly cited. doi: https://doi.org/10.1192/bjp.2021.189. Published by Cambridge University Press, 6th January 2022.

The above article was published with incorrect terms stating 'gender' when the correct term was 'sex'. This has now been updated in the online PDF and HTML versions of the article.

The Publisher apologises for the error.

\section{Reference}

1 Mutz J, Hoppen TH, Fabbri C, Lewis CM. Anxiety disorders and age- related changes in physiology. The British Journal of Psychiatry 2022; 1-10. doi: 10.1192/bjp.2021.189 